\title{
Evaluation of $\alpha$-Klotho, FGF-23 and Insulin Resistance in Obese Prediabetics
}

\author{
Çınar SEVERCAN ${ }^{1} \oplus \llbracket$, Ayşe Ceylan HAMAMCIOĞLU1 ${ }^{1}$, Taner BAYRAKTAROĞLU² ${ }^{2}$ \\ ${ }^{1}$ Zonguldak Bulent Ecevit University, Faculty of Pharmacy, Department of Biochemistry, Zonguldak, Turkey \\ ${ }^{2}$ Zonguldak Bulent Ecevit University, Faculty of Medicine, Department of Internal Medicine, Division of Endocrinology and Metabolism, \\ Zonguldak, Turkey \\ Cite this article as: Severcan Ç. et al. Evaluation of $\alpha$-Klotho, FGF-23 and Insulin Resistance in Obese Prediabetics. Turk J Diab Obes 2021;2: 131-136.
}

\begin{abstract}
Aim: Prediabetes is a condition with hyperglycemia and risk of development type 2 diabetes mellitus (T2DM). The aim of this study is to determine the concentrations of blood pressure, serum lipoproteins, glucose and insulin levels as well as the concentrations of $\alpha$-klotho and FGF-23 parameters. We also aim at the correlation between all these parameters in obese prediabetics and obese normoglycemics.

Material and Methods: A total of 26 obese normoglycemic (control group) and 25 obese prediabetic individuals were included in this study. Glucose, haemoglobin A1c (HbA1c) and cholesterols levels were analyzed as part of a routine procedure in the biochemistry laboratories of our hospital using an autoanalyzer. In order to determine $\alpha$-klotho and fibroblast growth factor-23 (FGF-23) levels, ELISA method was used. Student-t Test and Mann-Whitney U Test were used for evaluation of parameters' statistical analyzes. Spearman correlation test was used for correlation analysis.

Results: According to the findings, a significant increase was detected in serum LDL-C, TC, HbA1c, glucose, insulin and Homeostatic Model Assessment of Insulin Resistance (HOMA-IR) levels in the obese prediabetic group compared to the control group ( $\mathrm{p}<0.05$ ). However, serum $\alpha$-klotho and FGF-23 levels were found to be significantly lower in the obese prediabetic group compared to the control group ( $\mathrm{p}$ 0.05). $a$-klotho and FGF-23 values showed strong negative correlation when compared with HOMA-IR values separately ( $\mathrm{p}$ $<0.01)$.

Conclusion: These findings indicate that a-klotho and FGF-23 levels decrease in prediabetic patients and are associated with insulin resistance. The results of our study will make a significant contribution to the literature.
\end{abstract}

Keywords: Prediabetes, Insulin resistance, $\alpha$-klotho and fibroblast growth factor-23 (FGF-23)

\section{Obez Prediyabetiklerde $\alpha$-Klotho, FGF-23 ve İnsülin Direncinin Değerlendirilmesi}

\begin{abstract}
ÖZ
Amaç: Prediyabet, hiperglisemi ve tip 2 diabetes mellitus (T2DM) gelişme riski olan bir durumdur. Bu çalışmanın amacı, kan basıncı, serum lipoproteinleri, glikoz ve insülin düzeylerinin yanı sıra a-klotho ve FGF-23 parametrelerinin konsantrasyonlarını belirlemektir. Ayrıca obez prediyabetiklerde ve obez normoglisemilerde tüm bu parametreler arasındaki korelasyonu belirlemeyi hedefliyoruz.

Gereç ve Yöntemler: Toplam 26 obez normoglisemik (kontrol grubu) ve 25 obez prediyabetik birey bu çalışmaya dahil edildi. Hastanemizin biyokimya laboratuvarlarında rutin prosedür kapsamında glukoz, hemoglobin A1c (HbA1c) ve kolesterol seviyeleri otoanalizör kullanılarak analiz edildi. $\alpha$-klotho ve fibroblast büyüme faktörü-23 (FGF-23) düzeylerini belirlemek için ELISA yöntemi kullanıldı.

Bulgular: Bulgulara göre obez prediyabetik grupta serum LDL-C, TC, HbA1c, glikoz, insülin ve insülin direncinin homeostatik model değerlendirmesi (HOMA-IR) seviyelerinde kontrol grubuna göre anlamlı artış tespit edildi ( $\mathrm{p}<0.05)$. Ancak obez prediyabetik grupta
\end{abstract}

ORCID: Çınar Severcan / 0000-0002-3806-6406, Ayşe Ceylan Hamamcıoğlu / 0000-0003-3440-4700, Taner Bayraktaroğlu / 0000-0003-3159-6663 
serum $\alpha$-klotho ve FGF-23 düzeyleri kontrol grubuna göre anlamlı olarak düşük bulundu ( $\mathrm{p}<0.05)$. $\alpha$-klotho ve FGF-23 değerleri, HOMA-IR değerleri ile ayrı ayrı karşılaştırıldığında güçlü negatif korelasyon gösterdi $(\mathrm{p}<0.01)$. Parametrelerin istatistiksel analizlerinin değerlendirilmesinde Student-t Testi ve Mann-Whitney U Testi kullanıldı. Korelasyon analizi için Spearman korelasyon testi kullanıldı.

Sonuç: $\mathrm{Bu}$ bulgular prediyabetik hastalarda $\alpha$-klotho ve FGF-23 düzeylerinin düştüğünü ve insülin direnci ile ilişkili olduğunu göstermektedir. Çalışmamızın sonuçları literatüre önemli katkı sağlayacaktır.

Anahtar Sözcükler: Prediyabet, İnsülin direnci, $\alpha$-klotho ve fibroblast büyüme faktörü-23 (FGF-23)

\section{INTRODUCTION}

Prediabetes individuals generally have higher blood glucose than normal individuals but is not high sufficient to fulfill the diagnostic criteria for diabetes mellitus. It is a pathologic condition with high risk for the progress of diabetes. The definition of World Health Organization (WHO), for a person to be diagnosed as prediabetes, he or she should have fasting serum glucose levels between $100-125 \mathrm{mg} / \mathrm{dL}$ and the recorded oral glucose test results (OGTT) between 140-200 mg/dL (1). The percentage of haemoglobin Alc (HbAlc) was also added as another diagnostic criteria for diabetes by American Diabetes Association. Individuals with $\mathrm{HbAlc}$ values between $5.7 \%-6.4 \%$ were considered as prediabetic (2).

According to the 2016 report of WHO, 2 billion of people were reported as overweight or obese (3). More proinflammatory cytokines are being released from adipose tissue to blood in obese individuals compared to individuals with normal weight. Increasing reactive oxygen species together with proinflammatory cytokines can lead to the development of insulin resistance which then causes the development of prediabetes and / or diabetes (4-6). In a cross-sectional study involving 2022 participants, a strong relationship was found between prediabetes and obesity (7).

Klotho is a highly functional protein, first described in mice, in 1997. It has membrane-bound form as well as soluble form (8). Its membrane-bound form binds to a specific receptor in bone cells, allowing the secretion of Fibroblast Growth Factor-23 (FGF-23) hormone. It is known that FGF-23 inhibits urinary phosphate release, calcitriol [1,25 $(\mathrm{OH}) 2 \mathrm{D}$ ] secretion, and both the synthesis and secretion of parathyroid hormone (9). Soluble klotho ( $\alpha$-klotho) is found in the circulation and plays a role in the regulation of calcium balance in the kidneys (10). The role of klotho in reducing hyperglycemia and increasing glucose tolerance in experimental animal models has been reported (11).

Studies in the literature that associate $\alpha$-klotho and FGF-23 parameters with insulin resistance in obese prediabetics are insufficient. It is important to identify new markers that can give rapid results in diagnosis, since most of the prediabetic people are unaware of the situation and when they realise their condition, it may be late for them to take the necessary measures to protect themselves from type 2 diabetes mellitus (T2DM). The purpose of conducting this study to determine the concentrations of blood pressure, serum lipoproteins, glucose and insulin parameters, as well as the concentrations of a-klotho and FGF-23 parameters. We also investigated the correlation between all these parameters in obese prediabetics and in obese normoglycemics.

\section{MATERIAL and METHODS}

\section{Study Participants}

Power analysis was performed to determine the sample size using the GPower 3.1 program. In the relevant literature, the effect size was calculated as 1,073 in the interventional study conducted by Kutlutürk et al (12). The mean-standard error values of the groups were used and $\alpha=0.05$ and $1-\beta=0.95$ were selected, and the minimal sample size was determined as 19 for the obese prediabetic group and 21 for the obese normoglycemic group.

Prediabetic obese individuals and normoglycemic obese individuals were included in the study on their first visit to university's Obesity and Diabetes Research and Application Center. They all approved to be involved in this study and signed the consent forms. Participants who are nonsmokers and nonalcoholic, not under any type of medication and not taking vitamins, who are not pregnant, not breastfeeding and over 18 years of age were chosen for the study. The study consisted of two groups; Group 1: 26 obese normoglycemic individuals (control group, 18 females), and Group 2: 25 obese prediabetic individuals (patient group, 17 females).

\section{Variables}

For the study, gender, age, weight, height, body mass index (BMI), systolic blood pressure (SBP), diastolic blood pressure (DBP) and heart rate values were all obtained from individuals' files. Calculation of Homeostatic Model Assessment of Insulin Resistance (HOMA-IR) with the formula of Glucose (mg / dL) x Insulin ( $\mathrm{uIU} / \mathrm{mL}$ ) / 405 was determined whether insulin resistance or not $(13,14)$. 
Total cholesterol (TC), low-density lipoprotein cholesterol (LDL-C), high-density lipoprotein cholesterol (HDL-C), triglyceride (TG), Haemoglobin A1C (HbA1C), glucose and insulin levels were measured as part of a routine procedure in the biochemistry laboratory by using an autoanalyzer.

Blood samples taken from the participants were centrifuged, the sera were separated and stored at $-80^{\circ} \mathrm{C}$ deepfreezer until usage. Commercially available ELISA kits were used for klotho (Elabscience Biotechnology, Catalog number: E-EL-H5451) and for FGF-23 (Elabscience Biotechnology, Catalog number: E-EL-H1116). Klotho results were expressed in $\mathrm{ng} / \mathrm{ml}$ and FGF-23 results were expressed in $\mathrm{pg} / \mathrm{ml}$.

\section{Statistical Analysis}

Statistical Package for the Social Sciences (SPSS) version 25.0 was selected for the analysis of the data. Shapiro-Wilk test was chosen to understand the distribution of obese prediabetic group and obese normoglycemic group. Length, DBP, SBP, pulse, TC, LDL-C, HbA1C, glucose and FGF-23 evaluated using Student-t Test due to parametric test condition. Weight, BMI, HDL-C, TG, HbA1C, insulin, HOMA-IR and a-klotho values was evaluated using Mann-Whitney U Test because of non-parametric test condition. Significance was accepted if $\mathrm{p}$ value less than 0.05 . Spearman correlation test was used for correlation analysis.

\section{RESULTS}

According to the results of the study, a significant increase was measured in the age, LDL-C, TC, HbA1C, glucose, insulin and HOMA-IR levels in the obese prediabetic group compared to the obese normoglycemic control group ( $\mathrm{p}$ $<0.05)$. However, serum $\alpha$-klotho and FGF-23 levels were found to be significantly lower in the prediabetes group compared to the control group. However, when the two groups were compared, the statistical significance of the difference could not be found for weight, length, BMI, DBP, SBP, pulse, HDL-C and TG levels ( $p>0.05$ ) (Table 1).

According to the results of the correlation analysis, when the $a$-klotho and FGF-23 values of both groups were compared with HOMA-IR values separately, a strong significant negative correlation was found $(\mathrm{p}<0.01)(\mathrm{r}=-0.461,-0.641$; respectively). On the other hand, a strong positive correlation was found between $\alpha$-klotho and FGF-23 parameters of both groups $(\mathrm{p}<0.01)(\mathrm{r}=0.366)($ Table 2$)$.

Table 1: The comparison of demographic data and biochemical parameters between the obese normoglycemics (control group) and obese prediabetics.

\begin{tabular}{|c|c|c|c|}
\hline Groups/Variables & Obese normoglycemics $(n=26)$ & Obese prediabetics $(n=25)$ & $p$ values \\
\hline Age (Years) & 30.96 & 42.72 & $0.001^{*}$ \\
\hline Weight (kg) & $86(80.80-96.18)$ & $88(80.00-103.30)$ & 0.332 \\
\hline Length $(\mathbf{m})$ & $1.66 \pm 0.08$ & $1.64 \pm 0.09$ & 0.437 \\
\hline BMI $\left(\mathrm{kg} / \mathrm{m}^{2}\right)$ & $31.52(27.34-35.21)$ & $33.20(30.47-40.32)$ & 0.109 \\
\hline DBP (mmHG) & $78.81 \pm 9.16$ & $79.40 \pm 10.77$ & 0.833 \\
\hline SBP (mmHG) & $117.62 \pm 11.46$ & $123.52 \pm 18.82$ & 0.180 \\
\hline Pulse (mmHG) & $77.27 \pm 7.33$ & $75.68 \pm 10.05$ & 0.521 \\
\hline TC (mg/dl) & $171.16 \pm 30.84$ & $200.24 \pm 35.82$ & $0.003^{*}$ \\
\hline LDL-C (mg/dl) & $98.65 \pm 21.16$ & $124.56 \pm 31.49$ & $0.001^{*}$ \\
\hline HDL-C (mg/dl) & $50(41.00-56.25)$ & $45.0(40.50-51.00)$ & 0.295 \\
\hline TG (mg/dl) & $108.50(87.00-163.75)$ & $133.0(74.00-186.50)$ & 0.462 \\
\hline HbA1C & $5.2(5.0-5.6)$ & $5.6(5.4-5.9)$ & $0.001^{*}$ \\
\hline Glucose (mg/dl) & $94.96 \pm 6.97$ & $109.72 \pm 7.93$ & $0.001^{\star}$ \\
\hline Insulin (uIU/mL) & $14.09(10.35-18.05)$ & $19.06(13.24-26.79)$ & $0.023^{*}$ \\
\hline HOMA-IR & $3.20(2.39-4.35)$ & $5.17(3.70-7.55)$ & $0.002^{*}$ \\
\hline a-klotho (ng/ml) & $9.41(6.20-12.52)$ & $3.13(2.25-5.12)$ & $0.001^{\star}$ \\
\hline FGF-23 (pg/ml) & $40.58 \pm 8.65$ & $32.21 \pm 11.53$ & $0.005^{\star}$ \\
\hline
\end{tabular}

*: Significant differences between the two groups, Parametric variables are illustrated as mean \pm standard deviation; non-parametric variables as median (interquartile range). 
Table 2: Correlation among parameters

\begin{tabular}{lcccc}
\hline Parameters & & HOMA-IR & FGF-23 & Klotho \\
\hline \multirow{3}{*}{ HOMA-IR } & $\mathbf{r}$ & 1 & -0.641 & -0.461 \\
\cline { 2 - 5 } & $\mathbf{p}$ & - & $0.001^{* *}$ & $0.001^{* *}$ \\
\cline { 2 - 5 } & $\mathbf{n}$ & 51 & 51 & 51 \\
\hline \multirow{3}{*}{ FGF-23 } & $\mathbf{r}$ & -0.641 & 1 & 0.366 \\
& $\mathbf{p}$ & $0.001^{* *}$ & - & $0.008^{* *}$ \\
\hline \multirow{3}{*}{ Klotho } & $\mathbf{n}$ & 51 & 51 & 51 \\
& $\mathbf{r}$ & -0.461 & 0.366 & 1 \\
\hline & $\mathbf{p}$ & $0.001^{* *}$ & $0.008^{* *}$ & - \\
\hline
\end{tabular}

** Significant correlation $\mathrm{p}<0,01$ (2-tailed), FGF-23: Fibroblast growth factor, HOMA-IR: Homeostatic Model Assessment Insulin Resistance, , r: Correlation coefficient, p:Significance (2-tailed)

\section{DISCUSSION}

Obesity is a high risk condition for the development of prediabetes, diabetes and related complications (15). In developed countries, it has been shown that more than one third of adults have prediabetes, but most of these individuals are unaware of the situation (16). A treatment plan is required to prevent or slow down the transition from prediabetes to diabetes $(17,18)$. Therefore, detection and treatment of prediabetes is important in preventing diabetes. In addition, adults who are aware of prediabetes have a higher rate of taking precautions against diabetes than adults who are unaware of their condition (19).

While prediabetes is not a risk factor in the development of cardiovascular diseases without hypertension (20), hypertension together with prediabetes may be an important risk factor in the development of cardiovascular diseases (21). However, hypertension is twice as high in diabetic patients compared to those without diabetes (22).

According to the results of our study, no significant difference was found when DBP, SBP and pulse values of the control and prediabetes groups were compared. These results show that obese prediabetic individuals do not have high blood pressure risk compared to obese normoglycemic individuals.

Compared to controls, prediabetic patients show higher TG, LDL-C, and TC while showing decreased HDL-C $(23,24)$. In our study, a significant increase in TC and LDL-C levels and a non-significant increase in TG levels were observed in the obese prediabetic group. On the other hand, there was a non-significant decrease in serum HDL-C level in the obese prediabetic group.

It has been associated with low $\alpha$-klotho in both studies with diabetic rat models and clinical of T2DM patients (25-
29). It has been shown that in diabetic experimental animal models, with an elevation of plasma klotho level, insulin storage, acceleration of its synthesis and plasma insulin level also increased (11). Similarly, low serum klotho level and increased insulin resistance have been associated with T2DM patients (30). Although Gateva et al. found a decrease in the plasma klotho level in prediabetes patients, it was not significant. However, in this study, increased FGF23 was associated with increased glucose (31). Contrary to this study, Kutlutürk et al. showed that plasma insulin and glucose levels of obese prediabetes children increased, whereas serum $\alpha$-klotho and FGF-23 levels decreased. They associated insulin resistance with low FGF-23 level (12).

According to the results of our study, serum $\mathrm{HbA1C}$, glucose, insulin and HOMA-IR levels increased significantly when compared to the control group $(\mathrm{p}<0.05)$. In addition to this, serum $\alpha$-klotho and FGF-23 levels were found to be significantly lower than the controls. According to the results of correlation analysis, it was determined that a-klotho and FGF-23 parameters were negatively correlated with insulin resistance, while $\alpha$-klotho and FGF-23 parameters were positively correlated with each other $(\mathrm{p}<0.01)$.

The study results demonstrated that serum $\alpha$-klotho and FGF-23 levels decrease while TC, LDL-C, serum HbA1C, glucose, insulin and HOMA-IR levels increase in obese prediabetics when compared to obese normoglycemics. Together with this, a strong correlation between insulin resistance and serum $a$-klotho and FGF-23 levels was found. These findings indicate that $\alpha$-klotho and FGF-23 levels decrease in prediabetic patients and are associated with insulin resistance. In order to illuminate the underlying mechanisms, further studies, both experimental and clinical, are required to be performed with larger groups. 


\section{Acknowledgements}

The authors would like to thank Safiye Çatalcam and Ebru Boz Uzald 1 for their valuable contribution in collecting blood and consent forms of patients.

\section{Authors Contributions}

Çınar Severcan conducted ethical and project processes, laboratory experiments, statistical analysis and constitution of full text. Ayşe Ceylan Hamamcioğlu conducted laboratory experiments and translation of manuscript. Taner Bayraktaroğlu conducted admission and treatment of patients, determination of demographic variables and diagnosis of prediabetes.

\section{Conflict of Interest}

There is no conflict of interest among the authors.

\section{Financial Disclosure}

This project was supported by Zonguldak Bülent Ecevit University Scientific Research Projects with the number 2018-43085703-03.

\section{Ethical Approval}

Zonguldak Bülent Ecevit University Clinical Research Ethics Committee approved this study with the approval number 201842-31/01.

Peer Review Process

Extrmely peer reviewed.

\section{REFERENCES}

1. World Health Organization. Definition and diagnosis of diabetes mellitus and intermediate hyperglycemia: Report of a WHO/IDF consultation. $1^{\text {st }}$ Edition, WHO; IDF, 2006.

2. American Diabetes Association. Diagnosis and classification of diabetes mellitus. Diabetes Care. 2014;37(1):81-90.

3. World Health Organization (WHO). Obesity and Overweight. (Accessed April 2020, at http://www.who.int/mediacentre/ factsheets/fs311/en/)

4. Herder C, Carstensen M, Ouwens DM. Anti-inflammatory cytokines and risk of type 2 diabetes. Diabetes Obes Metab. 2013;15:39-50.

5. Luc K, Schramm-Luc A, Guzik TJ, Mikolajczyk TP. Oxidative stress and inflammatory markers in prediabetes and diabetes. J Physiol Pharmacol. 2019;70(6): 810-824.

6. Hamamcioglu, AC. The role of oxidative stress and antioxidants in diabetes mellitus. Turk J Diab Obes. 2017;1(1):7-13.

7. Sangrós FJ, Torrecilla J, Giráldez-García C, Carrillo L, Mancera J, Mur T, et al. Association of General and Abdominal Obesity With Hypertension, Dyslipidemia and Prediabetes in the PREDAPS Study. Rev Esp Cardiol (Engl Ed). 2018;71(3):170177.

8. Kuro-o M, Matsumura Y, Aizawa H, Kawaguchi H, Suga T, Utsugi T, Ohyama Y, Kurabayashi M, Kaname T, Kume E, Iwasaki H, Iida A, Shiraki-Iida T, Nishikawa S, Nagai R, Nabeshima YI. Mutation of the mouse klotho gene leads to a syndrome resembling ageing. Nature. 1997;390:45-51.
9. Komaba H, Fukagawa M. The role of FGF23 in CKD with or without Klotho. Nat Rev Nephrol. 2012;8:484-490.

10. Kitagawa $M$, Sugiyama $H$, Morinaga $H$, Inoue $T$, Takiue $K$, Ogawa A, Yamanari T, Kikumoto Y, Uchida HA, Kitamura S, Maeshima Y, Nakamura K, Ito H, Makino H. A decreased level of serum soluble Klotho is an independent biomarker associated with arterial stiffness in patients with chronic kidney disease. PLoS One. 2013;8:e56695.

11. Lin Y, Sun Z. In vivo pancreatic $\beta$-cell-specific expression of antiaging gene Klotho: A novel approach for preserving $\beta$-cells in type 2 diabetes. Diabetes. 2015;64(4):1444-1458.

12. Kutluturk Y, Akinci A, Ozerol IH, Yologlu S. The relationship between serum FGF-23 concentration and insulin resistance, prediabetes and dyslipidemia in obese children and adolescents. J Pediatr Endocrinol Metab. 2019;32(7):707-714.

13. Antuna-Puente B, Disse E, Rabasa-Lhoret R, Laville M, Capeau J, Bastard JP: How can we measure insulin sensitivity/ resistance? Diabetes Metab. 2011;37:179-188.

14. Mojiminiyi OA, Abdella NA. Effect of homeostasis model assessment computational method on the definition and associations of insulin resistance. Clin Chem Lab Med. 2010;48:1629-1634.

15. Boles A, Kandimalla R, Reddy PH. Dynamics of diabetes and obesity: Epidemiological perspective. Biochim Biophys Acta Mol Basis Dis. 2017;1863(5):1026-1036.

16. Mainous AG, Tanner RJ, Baker R, Zayas CE, Harle CA. Prevalence of prediabetes in England from 2003 to 2011: Population-based, cross-sectional study. BMJ Open. 2014;4(6):e005002.

17. Dunkley AJ, Bodicoat DH, Greaves CJ, Russell C, Yates T, Davies MJ, Khunti K. Diabetes prevention in the real world: Effectiveness of pragmatic lifestyle interventions for the prevention of type 2 diabetes and of the impact of adherence to guideline recommendations: A systematic review and metaanalysis. Diabetes Care. 2014;37(4):922-933.

18. Selph S, Dana T, Blazina I, Bougatsos C, Patel H, Chou R. Screening for type 2 diabetes mellitus: A systematic review for the U.S. Preventive Services Task Force. Ann Intern Med. 2015;162(11):765-776.

19. Gopalan A, Lorincz IS, Wirtalla C, Marcus SC, Long JA. Awareness of prediabetes and engagement in diabetes riskreducing behaviors. Am J Prev Med. 2015;49(4):512-519.

20. Hubbard D, Colantonio LD, Tanner RM, Carson AP, Sakhuja S, Jaeger BC, Carey RM, Cohen LP, Shimbo D, Butler M, Bertoni AG, Langford AT, Booth JN 3rd, Kalinowski J, Muntner P. Prediabetes and risk for cardiovascular disease by hypertension status in black adults: The Jackson Heart Study. Diabetes Care. 2019;42(12):2322-2329.

21. Liu HH, Cao YX, Li S, Guo YL, Zhu CG, Wu NQ, Gao Y, Dong QT, Zhao X, Zhang Y, Sun D, Li JJ. Impacts of prediabetes mellitus alone or plus hypertension on the coronary severity and cardiovascular outcomes. Hypertension. 2018;71(6):10391046.

22. Petrie JR, Guzik TJ, Touyz RM. Diabetes, hypertension, and cardiovascular disease: Clinical insights and vascular mechanisms. Can J Cardiol. 2018;34(5):575-584. 
23. Zhang L, Qiao Q, Tuomilehto J, Hammar N, Alberti KG, Eliasson M, Heine RJ, Stehouwer CD, Ruotolo G; DECODE Study Group. Blood lipid levels in relation to glucose status in European men and women without a prior history of diabetes: The DECODE Study. Diabetes Res Clin Pract. 2008;82(3):364377.

24. Mohieldein AH, Hasan M, Al-Harbi KK, Alodailah SS, Azahrani RM, Al-Mushawwah SA. Dyslipidemia and reduced total antioxidant status in young adult Saudis with prediabetes. Diabetes Metab Syndr. 2015;9(4):287-291.

25. Dokumacioglu E, Iskender H, Musmul A. Effect of hesperidin treatment on $a$-Klotho/FGF-23 pathway in rats with experimentally-induced diabetes. Biomed Pharmacother. 2019;109:1206-1210.

26. Ma Z, Li J, Jiang H, Chu Y. Expression of a-klotho is downregulated and associated with oxidative stress in the lens in streptozotocin-induced diabetic rats. Curr Eye Res. 2021;46(4):482-489.
27. Liu JJ, Liu S, Morgenthaler NG, Wong MDS, Tavintharan S, Sum CF, Lim SC. Association of plasma soluble $\alpha$-klotho with pro-endothelin-1 in patients with type 2 diabetes. Atherosclerosis. 2014;233(2):415-418.

28. Nie F, Wu D, Du H, Yang X, Yang M, Pang X, Xu Y. Serum klotho protein levels and their correlations with the progression of type 2 diabetes mellitus. J Diabetes Complications. 2017;31(3):594-598.

29. Zhang L, Liu T. Clinical implication of alterations in serum Klotho levels in patients with type 2 diabetes mellitus and its associated complications. J Diabetes Complications. 2018;32(10):922-930.

30. Silva AP, Mendes F, Pereira L, Fragoso A, Gonçalves RB, Santos N, Rato F, Neves PL. Klotho levels: Association with insulin resistance and albumin-to-creatinine ratio in type 2 diabetic patients. Int Urol Nephrol. 2017;49(10):1809-1814.

31. Gateva A, Assyov Y, Tsakova A, Kamenov Z. Prediabetes is characterized by higher fgf23 levels and higher prevalence of vitamin d deficiency compared to normal glucose tolerance subjects. Horm Metab Res. 2019;51(2):106-111. 